ーションができるようになったことを示している，従来 よりかなり容易になった感があり今後の応用を見たい。

演題36は連続撮影においてプログラム通り関連機器か 作動するか，タイミングのスレがないかをチェックする 場合，エックス線装置の回路に一切手を加えないで行う 方法を発表している。エックス線検出に虽光板を利用し た点がアイデアとして良いと感じ，日常われわれ技師が 保守管理を行う場合，簡単に操作できることが大きな利 点と考える。

演題37は福島県内における乳房撮影の現状と撮影条件 についての発表であった。ここで感じたことは県内20施 設中尃用装置で撮影を行っている所が 3 施設と少なかっ たことこのことは発表内容（乳房用ファントムによる 現出能测定の結果, $30 \mathrm{kV}$ 以下の電圧, ベリリウム空等の 条件が必要）でないと乳癌検出が困難である，に問題を 残すからである．専用装置が少ないことは作業件数が少 ない等の理由があると思うがわれわれ技師とすれば，専 用装置の設置が困難であれば一般装置での一部改良を含 み今後の改善の必要があると考える。

演題38は CT テープの保存性についてであった.CT テープの保管については従来より空調管理の中での保管 が必要とされているところであるが，保管量が多くなる と色々の問題が生じると思う。今回の発表は空調室外に テープを保管した場合の結果を見ている。この内容でも 明らかなように空調管理の必要は当然のことであるが, テープの特性等の問題もあり，永久的保存に関しては困 難であるとしている。

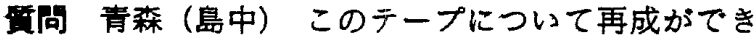
て，リサイクルができないと言うことは（リスライス） クリニングして再度の再成もできないと言うことか, 空 調しない所の温度変化の最高, 最低はどの程度か。

演題39 山形大学における放射線技師，医師，看護婦， の被眿線量をフィルムバッチによって10年間測定した結 果の発表であった。一般的に被曝線量軽減と言うと患者 サイドが多く問題視されがちで日常業務とし行っている われわれ技師について見るとマンネリ化している面も感 じる.

操作室区分によっての差があることは明らかであるが 技師の個人差が以外にも多いのには考えさせられた。術 者は患者サイドは勿論，自己の作業中の被曝軽減に向け さらに努めてほしい。

城新湯(長沢) 核医学部門で高被懪であることは うなずけるが，次に多い貫撮影について特定の方に多い 原因は。
鿓凮 岩手(樋口）今のわれわれの環境とすればかな り多いが，技師の心理状況は，被曝量の资料オープンに 対し問題はなかったか.

画像〔 I ]

40. 散乱線の因果问係

座長 鈴木正吾（東北大医療技術短大）

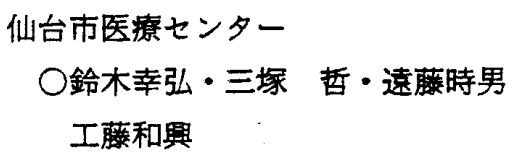

41. モンテカルロシミュレーションによる照射野面䅡と 散乱線典の成係の定量的静価 岩手医科大学中央放射線部
○视間沢博・菅野 茂 岩手医科大学放射線医学講座 桂川茂彦

〔目的〕X線撮影において，照射野を小さくすること により，散乱線の影響が軽隇する。しかし通常の測定法 では散乱線のみを分離し定量的に測定することは困難で ある。そこで照射野面稓の変化による散乱線量と線質を モンテカルロ法により求め定量的に評価する.

(結果) 照射野面積と散乱線量：10 cm の水ファント ムで管電王80 kvp では照射野面積を 2 倍にすると散乱 線量が1.77倍に，4 倍で2.54倍になり，入射線量に対す る透過 X線と散乱線の割合は照射野面穔に関係なく一定 であった.

散乱線の線質：照射野面䅐の賈化による散乱線の線質 は，平均エネルギーで見るかぎ変化はなかった。以上 モンテカルロ法により散乱線量と線質を定量的に評価で きた。

\section{PDM-5B の周波数特性について} 東北莪信病院放射線科 大久敏弘

ミクロホトメータ PDM-5B を使用して MTFやウィ ナースペクトルを測定すると，資料台の移動速度によっ て測定値が異なることがある.その原因を PDM-5B 内部 のアンプ系の周波特性によるものと考え，回路解析を行 い, 周波数特性を測定したところ, 入力周波数が $1 \mathrm{~Hz}$ 以 上になると急激にゲインが低下するのが確俛された。 ま た, PDM-5B の出力には電㭱レベルによらず一定值のピ ークを持つノイズが重荁しているのがオシロスコープに より観測された．以上の二点はコンピュータとのオンラ イン計測の場合大きな閴となる。 そこで, PDM-5Bの 周波数特性と雑音に関して回路的な検討を行い改善した ので報告した。 